\title{
A Study on the Seismic Response Characteristics of an Oblique Pile Group-Soil-Structure with Different Pile Caps
}

\author{
Desen Kong $\mathbb{D}^{1,2}$ Yifei Bai, ${ }^{1}$ Yongpo Chen, ${ }^{3}$ and Meixu Deng $\mathbb{D}^{1}$ \\ ${ }^{1}$ College of Civil Engineering and Architecture, Shandong University of Science and Technology, Qingdao 266590, China \\ ${ }^{2}$ Shandong Key Laboratory of Civil Engineering Disaster Prevention and Mitigation, Qingdao 266590, China \\ ${ }^{3}$ Shandong Zhengyuan Construction Project Co., Ltd., Jinan 250000, China \\ Correspondence should be addressed to Desen Kong; skd992012@sdust.edu.cn
}

Received 2 August 2019; Accepted 10 October 2019; Published 30 October 2019

Academic Editor: Hamid Toopchi-Nezhad

Copyright ( $\odot 2019$ Desen Kong et al. This is an open access article distributed under the Creative Commons Attribution License, which permits unrestricted use, distribution, and reproduction in any medium, provided the original work is properly cited.

\begin{abstract}
For the study of interaction between piles-soil-structure with different caps, the FLAC3D finite difference software was used as the research tool, and dynamic load was El Centro seismic wave. The numerical model of obliquely pile groups of the pile-soil-structure with low cap and high cap was established, respectively. The variation of pore pressure, the moment, the displacement of piles, and the displacement of pier was analyzed. The results indicate that under the action of earthquake, the distribution of pore water pressure in the soil layer increases gradually from top to bottom. The instantaneous negative value of partial soil due to shear dilation occurs at the peak of vibration acceleration. The middle area of the pile foundation in sandy soil is prone to liquefaction. In the same model, the maximum bending moment of inclined piles is greater than that of vertical piles. The vertical displacement of the vertical piles is a constant value along the depth, while the vertical displacement of the inclined piles is changed along the depth of the buried piles. In the high cap model, the horizontal displacement of the inclined piles is no longer monotonous along the burying depth, and the maximum value occurs in the sand soil layer. The vertical and horizontal displacements of the inclined piles and vertical piles in the high cap model are obviously greater than those of the low cap model. The maximum horizontal displacement of the pier of the two models occurs at the same time.
\end{abstract}

\section{Introduction}

According to the results of earthquake disaster investigations, soil liquefaction is one of the important reasons for the damage of pile foundation bridge structures [1]. With the vigorous development of the bridge undertakings in China, applications of the oblique pile group foundations are becoming increasingly common [2-4]. In addition, with the wide distribution and multiple earthquakes in China, most of the areas where bridges are built are very easy to liquefy. Therefore, whether soil liquefaction in earthquakes leads to the destruction of the pile foundation bridge structure of oblique and straight groups has become a problem that needs to be seriously considered in the earthquake resistance of bridge projects in China [5]. Group piles with low caps and high caps are widely used in bridge engineering [6-8]. The dynamic interaction analysis of a pile-soil-structure in a liquefied site plays an important role in seismic research of bridge pile foundations and has attracted the attention of many scholars [9]. As the finite element method can better simulate the liquefaction effect and large deformation of soil, as well as the physical characteristics of the pile-soil dynamic interaction process, it has been widely used in the seismic problems of pile-based bridges in liquefaction sites $[10,11]$. For this reason, the numerical models of low and high caps of the pile-soil-bridge with inclined and straight alternating groups were established on the clay-sandy soil layer, respectively, by using FLAC3D finite difference software as a research tool. In this paper, the variation of pore pressure ratio, pile foundation stress and displacement, and the stress and displacement of the superstructure of the bridge under an earthquake condition are analyzed in detail.

\section{Establishment of the Numerical Calculation Model}

2.1. Selection of Seismic Waves. Through the observation of the time history of the El-Centro seismic wave acceleration 
shown in Figure 1, it is found that the greater acceleration is mainly concentrated in the first half of the time-history diagram. To reduce the computational burden, only the first 27 seconds of El Centro waves are used as seismic loads.

The first $27 \mathrm{~s}$ of seismic waves are filtered by SeismoSignal software. Figure 2(a) shows the graph of the relation between the acceleration and frequency before filtering. It can be observed that the acceleration amplitude is mainly distributed between 0 and $7 \mathrm{~Hz}$ segments, so the truncation frequency of filtering is $7 \mathrm{~Hz}$ for filtering processing, and the relation curve between the acceleration and frequency, shown in Figure 2(b), is obtained.

After the completion of filtering, the seismic waves are corrected at the baseline, and the corrected El Centro waves are shown in Figure 3. Using the El Centro seismic wave after the baseline correction as the dynamic load, the ground base and foundation is returned to the original position after the calculation, and there will be no continuous velocity and residual displacement [12].

2.2. Establishment of Geometric Models. To study the seismic response of the oblique pile group-soil-structure with different caps, the parameters of soil and piles were selected from "FLAC/FLAC3D foundation and engineering cases" [13]. The type of this site is type II.

2.2.1. Establishment of a Two-Layer Free Site Grid Model. The soil body models are all constructed with an 8-node solid grid, which is $40 \mathrm{~m}$ long, $30 \mathrm{~m}$ wide, and $30 \mathrm{~m}$ high. The center of the surface on the model is taken as the coordinate origin. The excavation part of the bearing platform is the same as the volume of the bearing platform: $4 \mathrm{~m}$ long, $4 \mathrm{~m}$ wide, and $1 \mathrm{~m}$ high; the upper part of the model consists of $2 \mathrm{~m}$ thick clay soil; the middle part is $27 \mathrm{~m}$ thick sand soil; and the bottom is a $1 \mathrm{~m}$ thick rock layer. Considering the calculation precision and the size requirements of the FLAC3D dynamic computation time step on the maximum grid during the establishment of the model, the whole free-field model has symbiotic features of 36,000 zones and 39,442 grid-points. Figure 4 shows the model of the free field.

The Mohr-Coulomb model [14] is adopted for both layers of soil, and the isotropic elastic model is adopted for the bottom rocks. In the selection of the groundwater seepage model, the isotropic seepage model (fl_isotropic) is adopted for both layers of soil. The model of impervious material (fl_null) is adopted in the bottom strata. The groundwater fills the whole soil layer, as shown in Table 1.

2.2.2. Establishment of an Oblique Group Pile-Bridge Structure Model with Low Caps. The inclined pile and vertical pile are simulated by the pile structural element. The simulation of the bridge superstructure is realized by a beam element. Figure 5 shows the model of the pile group-pile cap-bridge structure system is established by FLAC3D finite difference software.
The pile cap model is built with an 8-node solid grid, $4 \mathrm{~m}$ long, $4 \mathrm{~m}$ wide, and $1 \mathrm{~m}$ thick. The pile foundation is a group of $2 \times 2$ piles, including 2 inclined piles and 2 vertical piles. The pile body is simulated by a pile structure unit. Each pile foundation includes 8 pile members (pilesel). The vertical pile is $10 \mathrm{~m}$ long, and the inclined pile has a tilt angle of $12^{\circ}$. The inclined pile and the vertical pile have the same elevation. The top of the pile is inserted into the platform at $0.5 \mathrm{~m}$, and the freedom of the top node is fixed. That is, it is set to a fixed end connection. The joints at the end of the pile body only limit the freedom of translational movement in three directions.

A beam element is adopted for the piers and the superstructure of the model. The piers are single-column piers with a beam length of $4 \mathrm{~m}$, and the lower part is inserted into the inner part of the bearing platform. The freedom of the lower joints is fixed (rigid), and the bottom end of the bridge pier is in the middle of the bearing platform, increasing the density of the top member of the beam element to simulate the upper structure of the bridge.

The interaction between the pile element and the oil mesh is realized by tangential and normal coupling springs, which are nonlinear and sliding connectors. The action mechanism of the tangential spring is equal to the tangential action of the grouting anchor. The normal spring can simulate the mutual squeeze between the pile and the soil. When the pile is subjected to a lateral load, cracks will appear between the pile and the soil. Normal springs are set with gap parameters to simulate cracks between piles and soils.

The constitutive relationship of the bridge bearing platform adopts an isotropic elastic model, the seepage model adopts the impervious water model (fl_null), the surface of the bearing platform is the same as the elevation of the ground, and the interface element is set around the bearing platform and the bottom surface. Figure 6 shows the piles of the bearing platform. Table 2 shows parameters of the pile element of the model. Table 3 shows parameters of the bridge structure and the interface.

\subsubsection{Establishment of an Oblique Group Pile-Bridge} Structure Model with High Caps. On the basis of the oblique group-pile-bridge structure model, the buried depth at the end of piles, the size of the cap, and the arrangement of piles have not changed, but the elevation of the cap has increased. The distance between the bottom of the cap and the ground level is $1.7 \mathrm{~m}$, as shown in Figure 7.

\section{Analysis of Numerical Results}

\subsection{Analysis of Seismic Response Characteristics of Foundation Soil}

3.1.1. Analysis of Pore Water Pressure. In the dynamic calculation stage, considering the reflection of seismic waves on the boundary, the free-field boundary is adopted as the boundary condition in the numerical simulation. After setting up, FLAC3D will generate four two-dimensional planar grids and four one-dimensional cylinder grids around the model, in which the planar grid is calculated in two 


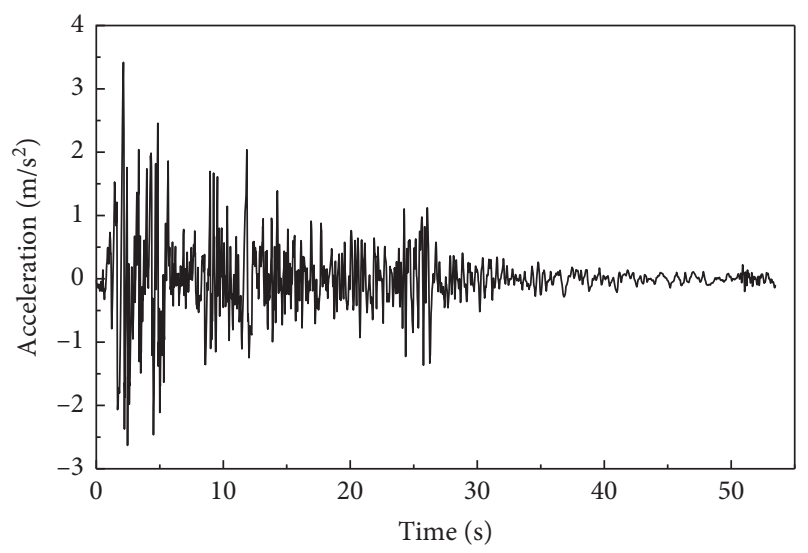

Figure 1: Acceleration and time curve of El Centro wave.

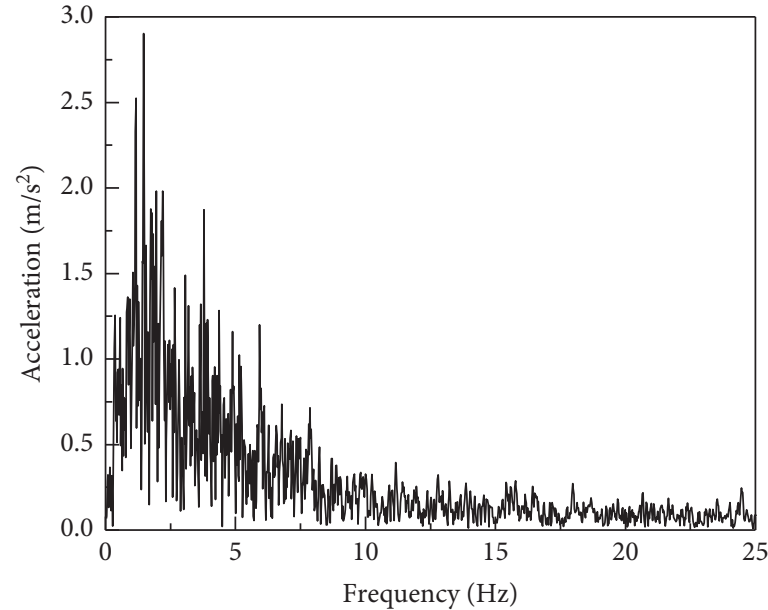

(a)

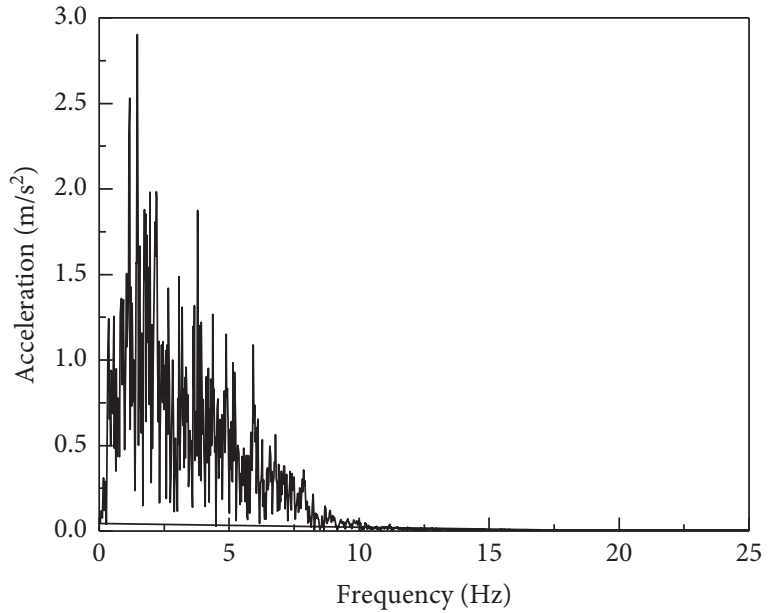

(b)

Figure 2: Acceleration-amplitude frequency diagram for the El Centro seismic wave before $27 \mathrm{~s}$. (a) Before filtering. (b) After filtering.

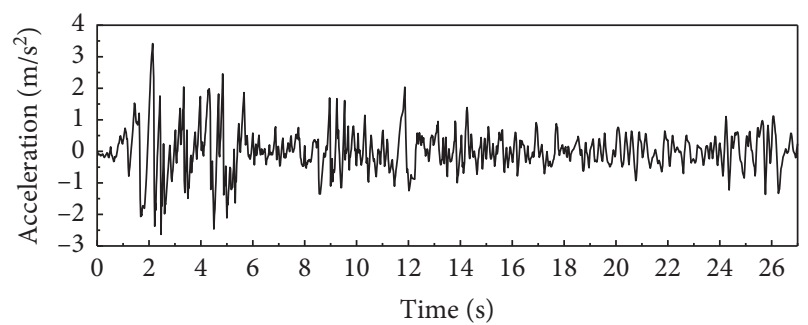

Figure 3: Corrected date of the seismic wave.

dimensions, assuming the normal extension of the plane to infinity, and the cylinder grid is calculated in one dimension, assuming the infinite extension at both ends of the cylinder. The dynamic model is shown in Figure 8.

FLAC3D provides a variety of dynamic load input types, including acceleration time interval, velocity time interval, stress time interval, and concentrated force time interval. A dynamic load is applied to the boundary or internal nodes of the model to simulate the response of the model when the model is driven internally or externally. Since the numerical

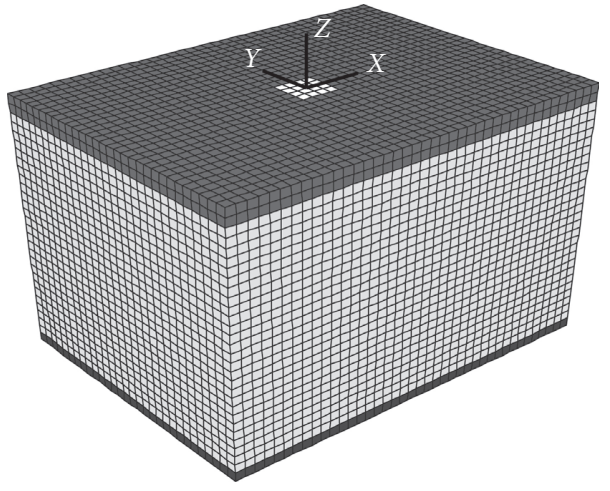

Figure 4: Model of the free field.

calculation load is input along the bottom of the model, and the bottom of the model is a rock stratum with a large modulus and belongs to a rigid foundation, the acceleration load is directly applied at the bottom of the model, and no static boundary conditions need to be set.

The adjusted El Centro seismic wave was used as the dynamic load. The peak acceleration is $0.35 \mathrm{~g}$, and the 
TABLE 1: Soil parameters of the free field.

\begin{tabular}{lcccccccc}
\hline $\begin{array}{l}\text { Layer } \\
\text { name }\end{array}$ & $\begin{array}{c}\text { Thickness } \\
(\mathrm{m})\end{array}$ & $\begin{array}{c}\text { Saturation density } \\
\left(\mathrm{kg} \cdot \mathrm{m}^{-3}\right)\end{array}$ & Porosity & $\begin{array}{c}\text { Cohesion } \\
(\mathrm{kPa})\end{array}$ & $\begin{array}{c}\text { Bulk modulus } \\
(\mathrm{MPa})\end{array}$ & $\begin{array}{c}\text { Shear modulus } \\
(\mathrm{MPa})\end{array}$ & $\begin{array}{c}\text { Internal friction } \\
\text { angle }\left({ }^{\circ}\right)\end{array}$ & $\begin{array}{c}\text { Permeability } \\
\mathrm{coefficient}\left(\mathrm{cm} \cdot \mathrm{s}^{-1}\right)\end{array}$ \\
\hline Clay & 2 & 1850 & 0.61 & 10 & 14.6 & 5.7 & 25 & $1 \times 10^{-7}$ \\
Sand & 27 & 2060 & 0.45 & 0 & 30 & 11 & 32 & $1 \times 10^{-2}$ \\
Rock & 1 & 2700 & 0 & - & 67000 & 31000 & - & 0 \\
\hline
\end{tabular}

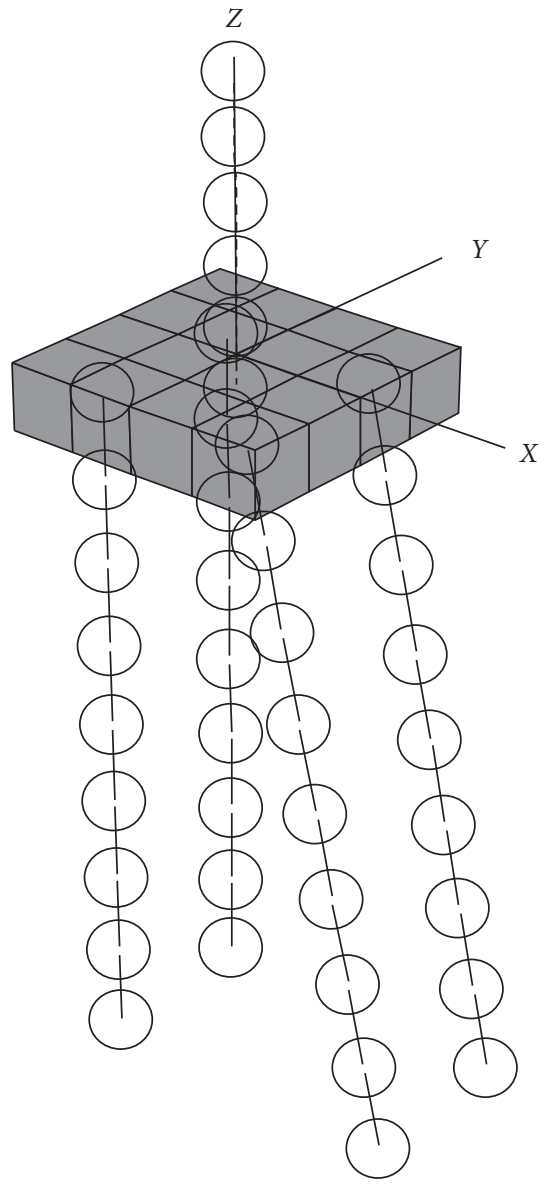

FIgURE 5: Computational model of the pile group-pile cap-bridge structure system.
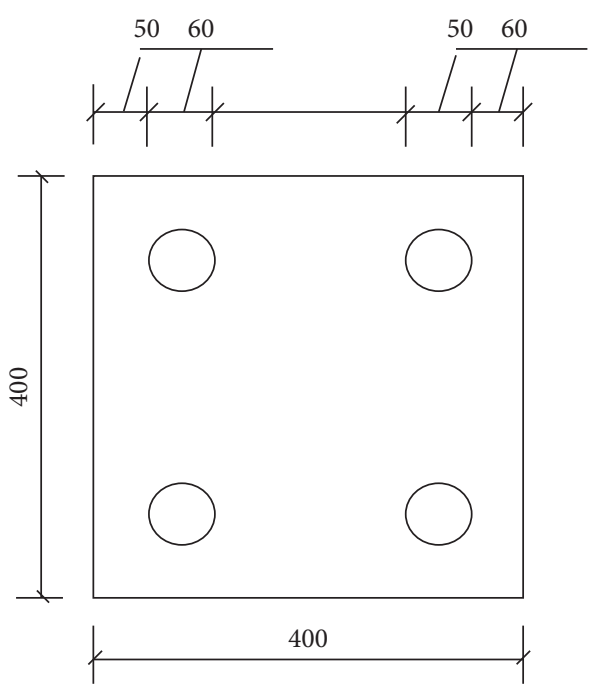

Figure 6: The cushion cap and pile arrangement. dynamic load is applied to the bottom of the model, along the $x$-axis. The displacement, force, and pore pressure ratio of the structure are monitored during calculation. A vertical section is made along the $x$-axis, that is, four units a, b, c, and $\mathrm{d}$ are monitored in the plane composed of the $x$-axis and $z$-axis. The monitoring contents include over pore pressure ratio, ultrastatic pore water pressure, vertical effective stress, and so on. Figure 9 shows the location of the monitoring point. Table 4 shows the coordinates of the four points monitored.

Figure 10 shows that maximum pore water pressure of this model is $0.39 \mathrm{MPa}$, while the initial pore pressure is $0.29 \mathrm{MPa}$. The largest pore water pressure increases by approximately $35 \%$, and the distribution of pore water pressure is still a gradual top-down increase. The maximum pore water pressure occurs about $2 \mathrm{~m}$ above the bottom surface of the sandy soil layer, and it has a wide distribution range.

The time-history curve of monitored four-point pore pressure ratio is shown in Figure 11. As seen from the curves, the pore pressure before $1.5 \mathrm{~s}$ basically does not change; after $1.5 \mathrm{~s}$, with the increase of acceleration amplitude, the pore pressure ratio begin to rise sharply, while at $2.1 \mathrm{~s}$, it reaches the maximum acceleration amplitude of $0.35 \mathrm{~g}$. At this point, the pore pressure ratio is an instantaneous negative value at point a and point $\mathrm{c}$; an analysis of the causes may indicate that the acceleration peak moment arrived in liquefied soil is caused by the instantaneous dilatancy effect.

In $3 \mathrm{~s}$, the pore pressure ratio of point $\mathrm{b}$ and point $\mathrm{d}$ of the pile foundation reaches 1 , indicating that the sand began to liquefy, and then the pore pressure ratio of point $\mathrm{d}$ decreased to a certain extent. The pore pressure ratio of point $c$ remained at approximately 0.8 after $3 \mathrm{~s}$ and did not fully liquefy. Point a began to liquefy after $7 \mathrm{~s}$, and its pore pressure ratio fluctuated between 0.8 and 1 after $7 \mathrm{~s}$.

The reason for the aforementioned phenomenon is that the initial pore pressure of the water in a is relatively small. The ultrapore water pressure does not reach the initial effective stress of sand, and the pore pressure ratio is due to the penetration of the groundwater through the upper clay layer. The consolidation pressure at point $c$ is large, and the consolidation degree of the sand and soil is high, so it is not easy to liquefy. However, since point $b$ and $d$ are located in the middle part of the pile, the same phenomenon of point a and point $\mathrm{c}$ will not occur.

3.1.2. Analysis of Soil Acceleration. In the calculation process, the soil layers in the distant field at different depths far from the pile foundation were monitored in the $x$-direction, and the acceleration time-history curve, shown in Figure 12, 
TABLe 2: Parameters of the pile element.

\begin{tabular}{|c|c|c|c|c|c|c|c|c|c|}
\hline Name & $\begin{array}{c}\text { Angle } \\
\left({ }^{\circ}\right)\end{array}$ & $\begin{array}{l}\text { Length } \\
\text { (m) }\end{array}$ & $\begin{array}{c}\text { Diameter } \\
(\mathrm{m})\end{array}$ & $\begin{array}{l}\text { Modulus } \\
\text { of } \\
\text { elasticity } \\
\text { (GPa) }\end{array}$ & $\begin{array}{l}\text { Poisson's } \\
\text { ratio }\end{array}$ & $\begin{array}{c}\text { Tangential } \\
\text { coupling spring } \\
\text { stiffness }(\mathrm{GPa})\end{array}$ & $\begin{array}{c}\text { Tangential } \\
\text { coupling spring } \\
\text { adhesive strength } \\
(\mathrm{kPa})\end{array}$ & $\begin{array}{l}\text { Normal } \\
\text { coupling } \\
\text { spring } \\
\text { stiffness } \\
(\mathrm{GPa})\end{array}$ & $\begin{array}{l}\text { Normal coupling } \\
\text { spring adhesive } \\
\text { strength }(\mathrm{kPa})\end{array}$ \\
\hline $\begin{array}{l}\text { Vertical } \\
\text { pile }\end{array}$ & 0 & 10 & 0.6 & 40 & 0.3 & 23.4 & 97.4 & 2.34 & 97.4 \\
\hline $\begin{array}{l}\text { Inclined } \\
\text { pile }\end{array}$ & 12 & 10.2 & 0.6 & 40 & 0.3 & 23.4 & 97.4 & 2.34 & 97.4 \\
\hline
\end{tabular}

TABle 3: Parameters of the bridge structure and the interface.

\begin{tabular}{|c|c|c|c|c|c|c|c|}
\hline Name & $\begin{array}{l}\text { Modulus of elasticity } \\
(\mathrm{GPa})\end{array}$ & $\begin{array}{l}\text { Poisson's } \\
\text { ratio } \\
\end{array}$ & $\begin{array}{l}\text { Density } \\
\left(\mathrm{kg} \cdot \mathrm{m}^{-3}\right)\end{array}$ & $\begin{array}{l}\text { Normal stiffness } \\
(\mathrm{MPa})\end{array}$ & $\begin{array}{c}\text { Tangential stiffness } \\
(\mathrm{MPa})\end{array}$ & $\begin{array}{c}\text { Internal friction } \\
\text { angle }\left({ }^{\circ}\right)\end{array}$ & $\begin{array}{c}\text { Cohesion } \\
(\mathrm{kPa})\end{array}$ \\
\hline Pier & 40 & 0.3 & 2400 & - & - & - & - \\
\hline $\begin{array}{l}\text { Additional } \\
\text { weight }\end{array}$ & 40 & 0.3 & 24000 & - & - & - & - \\
\hline Interface & - & - & - & 100 & 100 & 14 & 8 \\
\hline
\end{tabular}

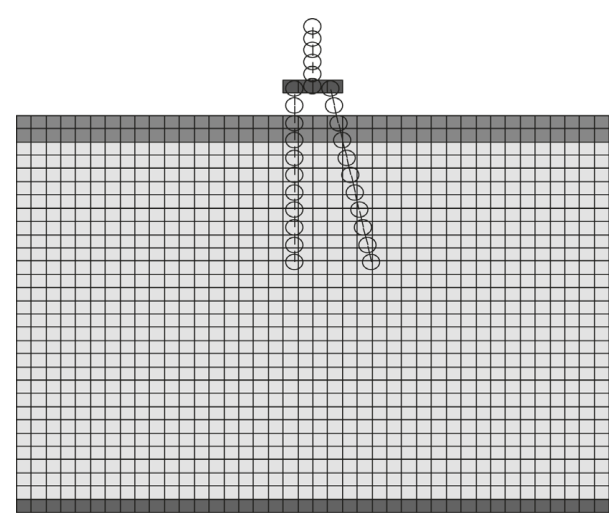

FIgURE 7: The static calculation model.

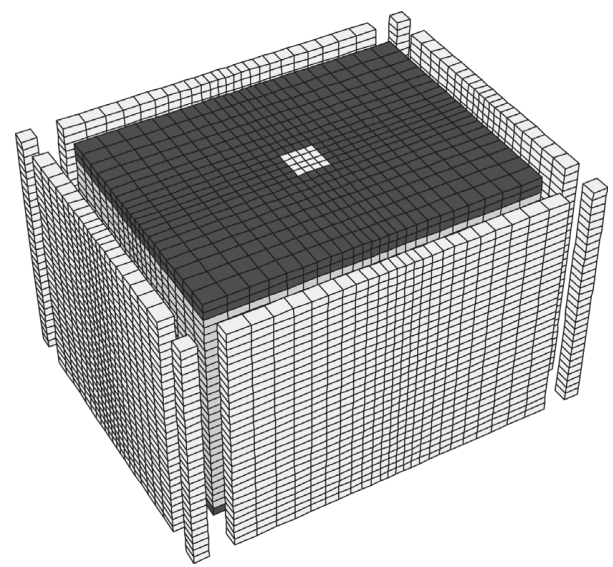

FIgURE 8: Dynamic calculation model.

was obtained. It is observed from the figure that the maximum acceleration peak of the soil at each position is greater than the input acceleration peak, and the maximum acceleration increases with the soil depth.

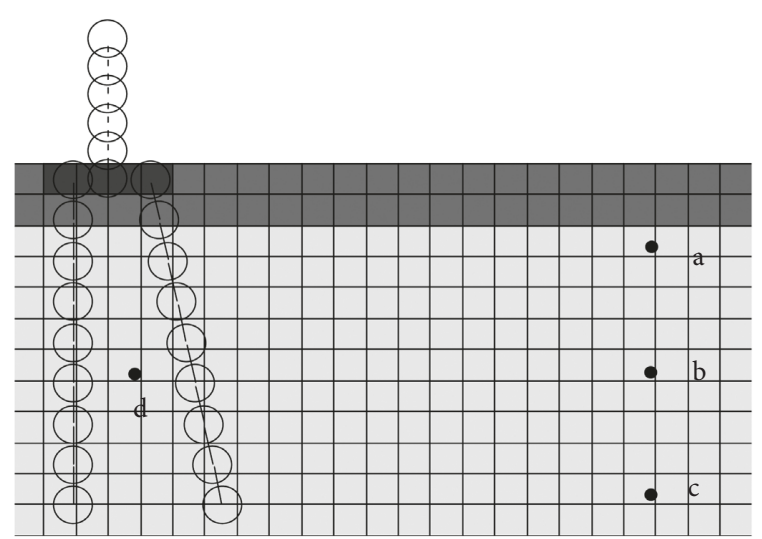

FIgURE 9: Arrangement of the monitoring location.

TABLE 4: Information of the monitoring location.

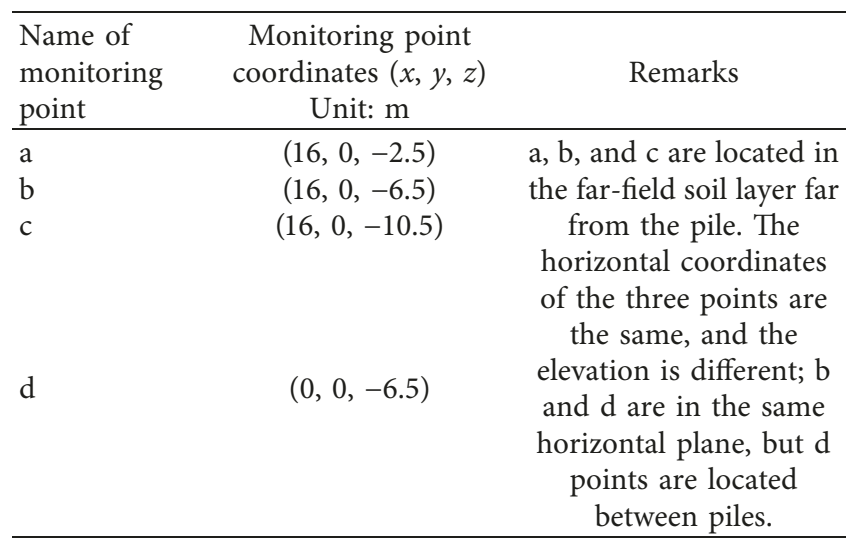

The analytic reason is that the dynamic load is input at the bottom of the soil. As the energy travels upward, as the buried depth decreases, the energy is gradually consumed and the acceleration peak decreases. The existence of maximum instantaneous acceleration should be caused by the existence of a large modulus of the rock layers. 


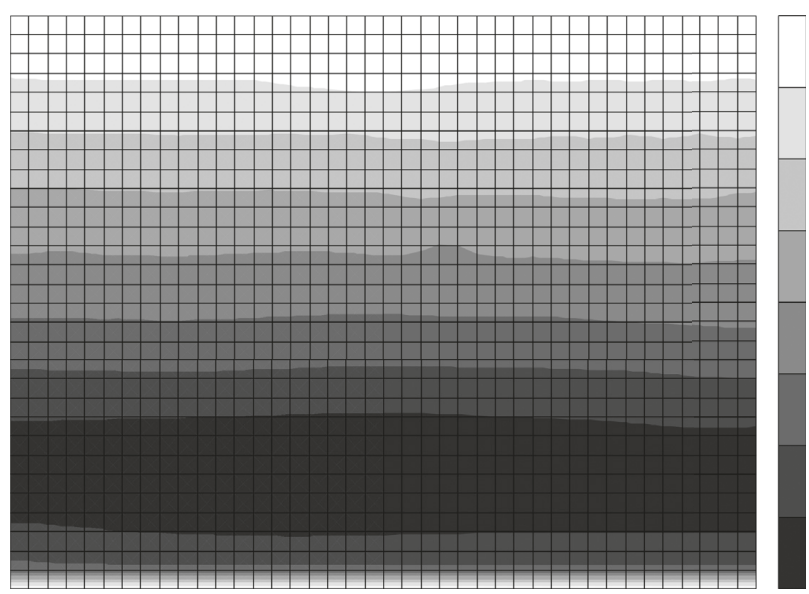

$0.0000 e+000$ to $5.0000 e+004$

$5.0000 e+004$ to $1.0000 e+005$

$1.0000 e+005$ to $1.5000 e+005$

$1.5000 e+005$ to $2.0000 e+005$

$2.0000 e+005$ to $2.5000 e+005$

$2.5000 e+005$ to $3.0000 e+005$

$3.0000 e+005$ to $3.5000 e+005$

$3.5000 e+005$ to $3.8927 e+005$

FIgURe 10: Contour of the pore pressure.

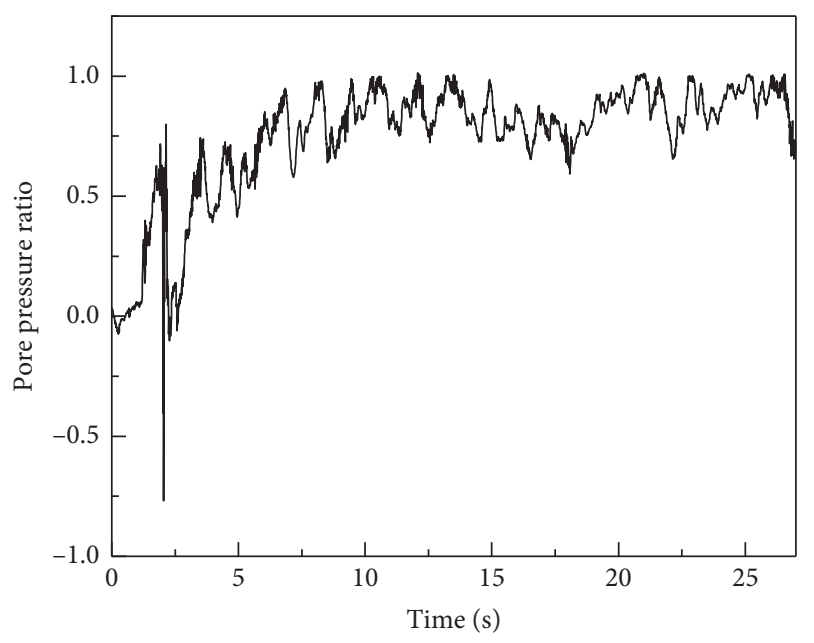

(a)

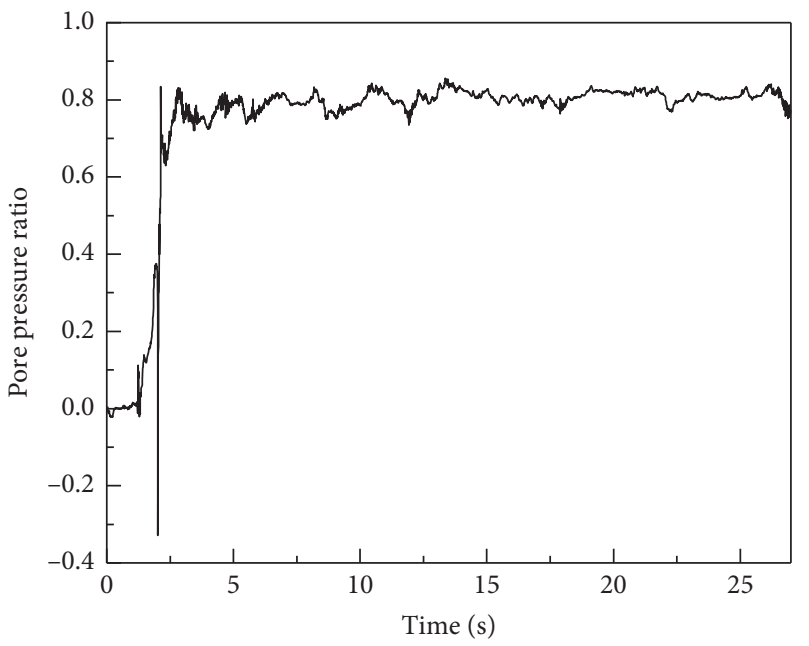

(c)

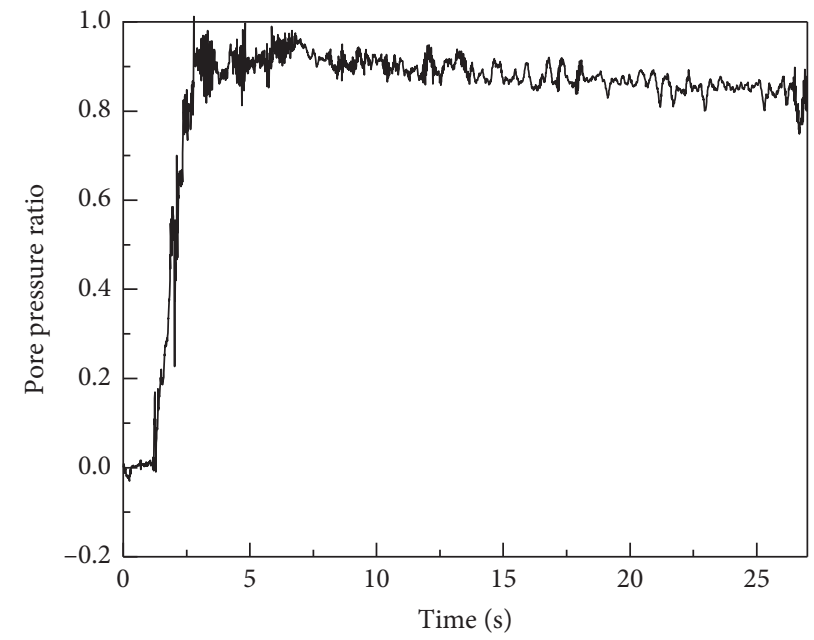

(b)

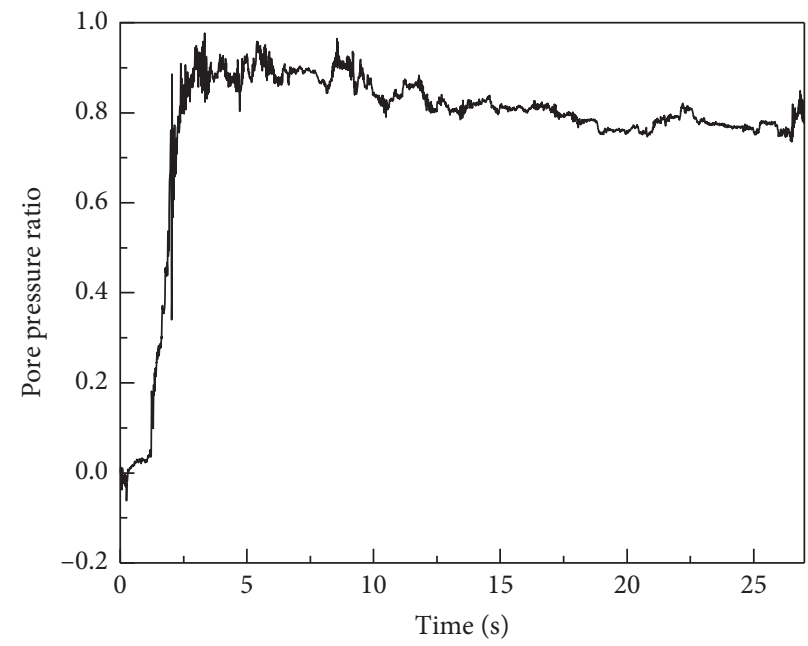

(d)

Figure 11: The time-history curves of the pore pressure ratio. (a) Pore pressure ratio at point a. (b) Pore pressure ratio at point b. (c) Pore pressure ratio at point $c$. (d) Pore pressure ratio at point $d$. 


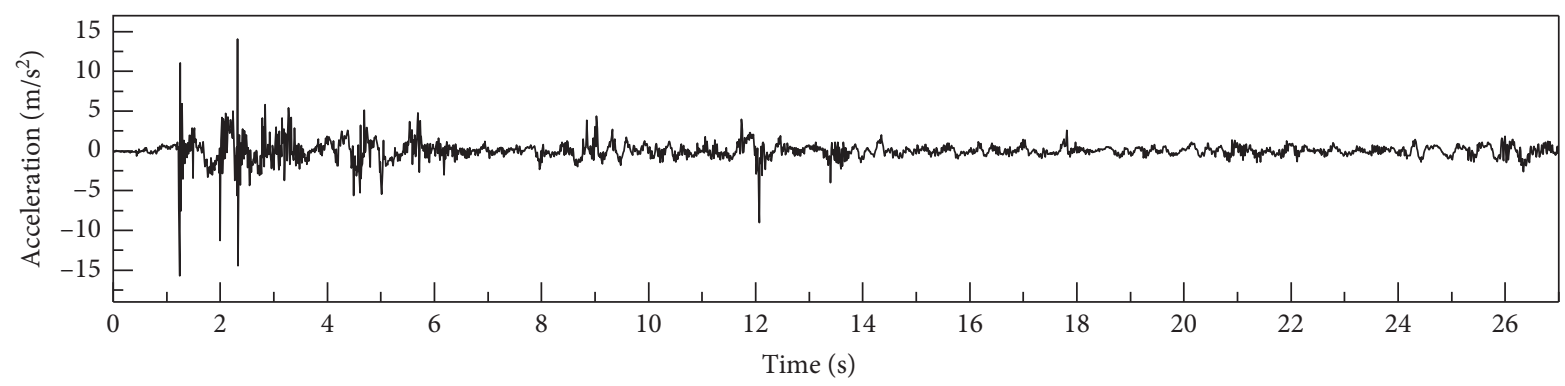

(a)

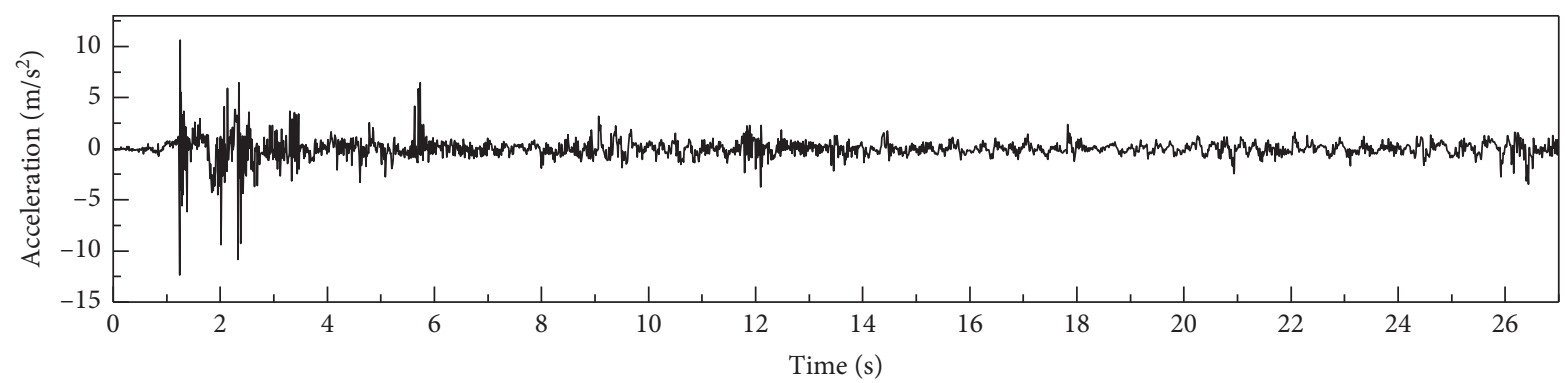

(b)

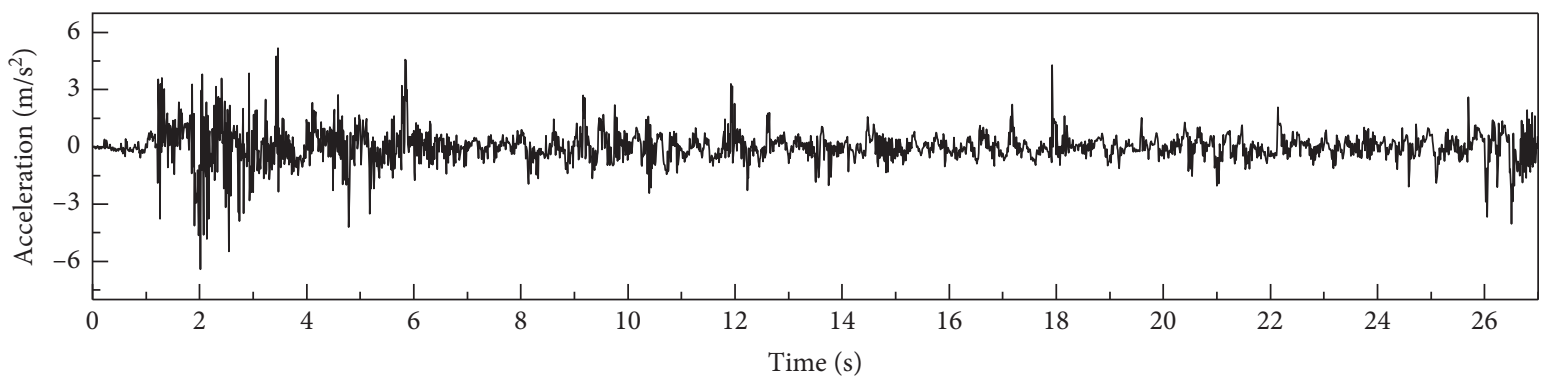

(c)

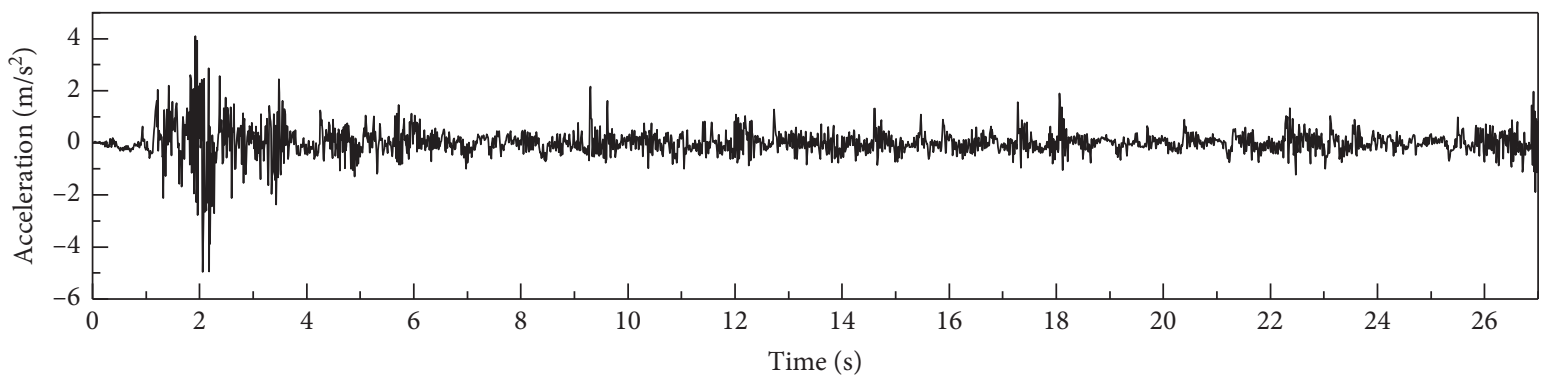

(d)

Figure 12: Soil acceleration time-history curve. (a) Depth $28 \mathrm{~m}$. (b) Depth $20 \mathrm{~m}$. (c) Depth $10 \mathrm{~m}$. (d) Depth $1 \mathrm{~m}$.

\subsection{Analysis of Seismic Response Characteristics of the Oblique Pile Group-Soil-Structure with Different Pile Caps}

3.2.1. Analysis of the Bending Moment of the Piles. In the whole acceleration process, the maximum bending moment of pile foundation with different buried depths was extracted, and the envelope diagram of the pile foundation bending moment was obtained, as shown in Figure 13.

The figure shows that the maximum bending moment of vertical and inclined piles occurs at the junction of the pile and the bearing platform, and the maximum bending moment of the inclined pile is approximately 16\% higher than that of the vertical pile, indicating that the force of the vertical pile is more favorable at the junction of the pile body and the bearing platform. The maximum bending moment of the two piles is zero at the base of the pile and increases gradually with the decrease of buried depth.

The reason for the above analysis is that when the model is established, the pile bottom elevation of the two pile foundations is the same. So, the total length of the inclined piles is more longer. Therefore, when the piles are subjected to the same force, the long arm at the top of the inclined pile increases the bending moment value of the pile. Moreover, the frictional resistance of the soil around the pile decreases after liquefaction. The vertical supporting force of the pile increases, and the supporting force at the bottom of the 


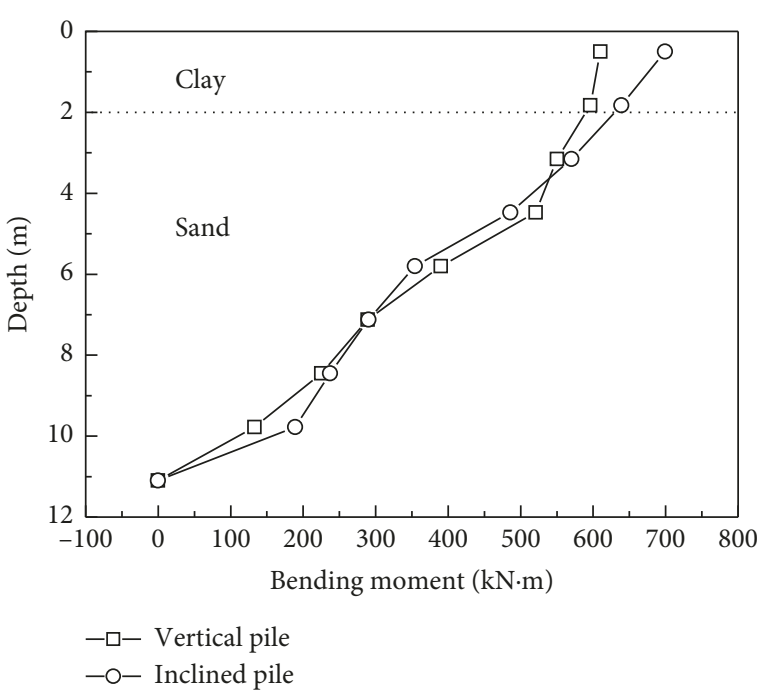

Figure 13: Pile moment and depth curve.

vertical pile coincides with the pile axis, which will not increase the bending moment at the top of the pile. In addition, the supporting force at the bottom of the inclined pile does not exactly coincide with the pile axis, thus increasing the moment at the top of the pile. Since the model only fixed the translational freedom at the bottom of the pile element and did not restrict the rotation freedom, the moment of the pile foundation at the bottom was zero.

3.2.2. Analysis of Pile Displacement. The vertical displacement of the pile body at different burial depths was monitored, and the maximum displacement of each part during the whole calculation stage was extracted to obtain the curve of vertical displacement and buried depth of piles, as shown in Figure 14.

The maximum vertical displacement of the whole pile is the same. The maximum vertical displacement of the inclined pile at the top position is the smallest. The maximum vertical displacement of the pile increases monotonically with the increase of the buried depth. The maximum vertical displacement occurs at the bottom of the pile, slightly greater than that of the vertical pile. It indicates that the inclined pile can better control the subsidence of the superstructure.

It can be observed from Figure 15 that the maximum horizontal displacement of the inclined piles and the vertical piles appears at the top of the pile, and the value is the same. The maximum horizontal displacement of the vertical and inclined piles above $8 \mathrm{~m}$ is similar. With the increase of the buried depth, the displacement of the pile body decreases gradually, and the maximum horizontal displacement of the inclined vertical piles at the bottom of pile reaches the minimum value, and the maximum horizontal displacement of the vertical pile is more greater.

\subsection{Analysis of Seismic Response Characteristics of the Oblique Pile Group-Soil-Structure with Different Pile Caps}

\subsubsection{Analysis of the Bending Moment of the Piles.}

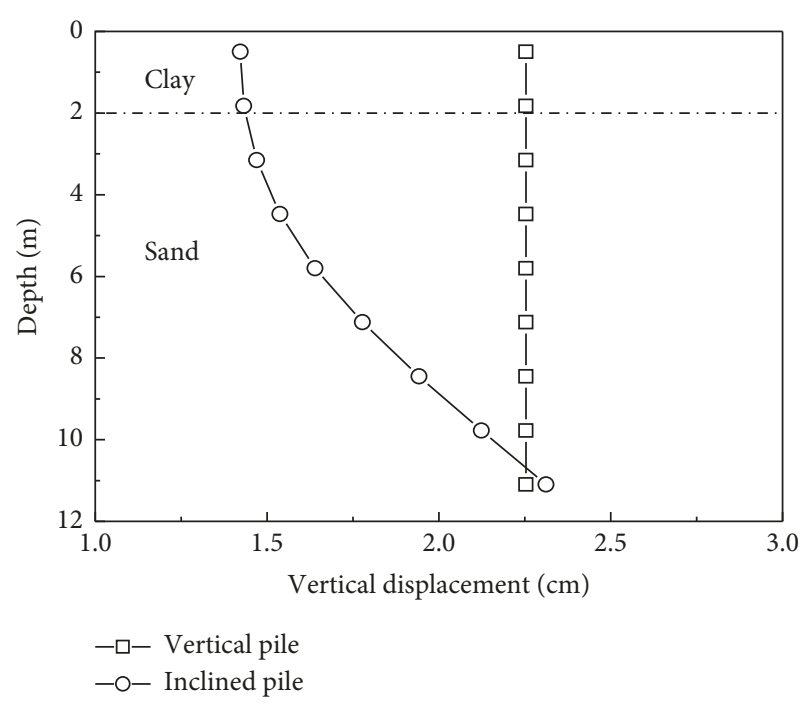

FIgURE 14: Vertical displacement of the piles.

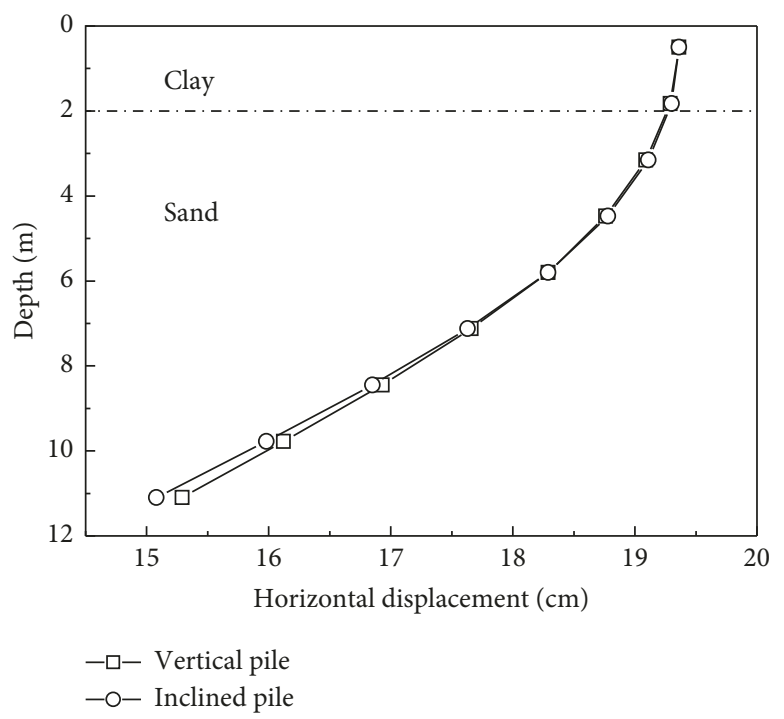

FIgURE 15: Horizontal displacement of the piles.

Extracting the maximum bending moment of pile foundation with different buried depth in the whole dynamic analysis stage, the envelope diagram of pile foundation bending moment is obtained, as shown in Figure 16. From the analysis in the figure, it can be seen that the bending moment at the joint of the pile and cap reaches the maximum value, and the minimum value is zero, which occurs at the end of the pile. The bending moment of the pile decreases gradually from the bottom of the pile cap to the ground level, while it does not change significantly in the clay layer but decreases monotonously with the increase of buried depth in the sand layer. The bending moment of the inclined pile is greater than that of the straight pile in the upper part of the pile, but opposite in the lower part of the pile.

The maximum bending moment of the inclined pile is larger than that of the straight pile because of the longer length of the inclined pile. The bending moment has little 


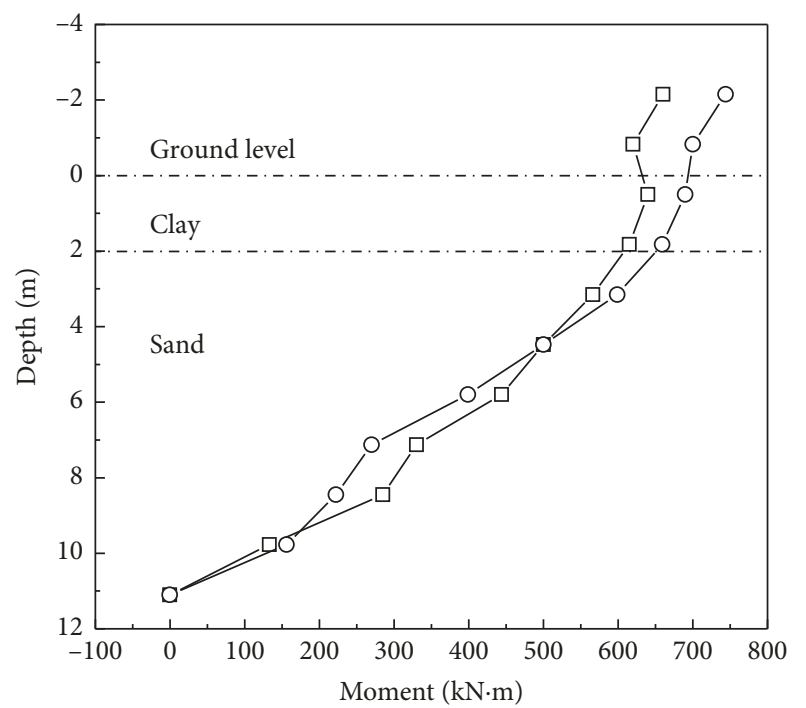

- - Vertical pile

-O- Inclined pile

FIgURE 16: Moment envelope diagram of piles.

change between the cap and the interface of clay and sand soil. It should be caused by the binding effect of the clay layer on the pile and the length of the pile between the cap and ground level after liquefaction of sand soil.

3.3.2. Analysis of Pile Displacement. It can be seen form Figure 17 that the maximum vertical displacement of the vertical pile is a constant value. The maximum vertical displacement of the inclined pile appears at the end of the pile, and the minimum displacement occurs in the middle of the pile in the sand layer. The vertical displacement of inclined piles is greater than that of vertical piles.

3.3.3. Analysis of the Causes of the Aforementioned Phenomena. Since the lateral force on the pile is weakened after liquefaction of sand soil, the inclined pile is inclined in the process of sinking. Therefore, the inclined pile bends upward in the middle of the pile, reducing the vertical displacement of the pile.

In Figure 18, the horizontal displacement of inclined and vertical piles at the top of piles is the same, and the minimum horizontal displacement of both piles occurs at the end of pile. The maximum displacement of a vertical pile occurs at the top of the pile. With the increase of buried depth, the displacement decreases monotonously, and the decreasing rate of the displacement from the top to the bottom of the pile increases gradually. Horizontal displacement of the inclined pile is not monotonous. The upper part of the pile increases with the depth of burial, while the lower part of the pile decreases with the depth of burial. The reason for this phenomenon is that the maximum horizontal displacement of the vertical pile appears at the joint of the pile cap. Pile side constraint increases gradually with the increase of buried depth, so the

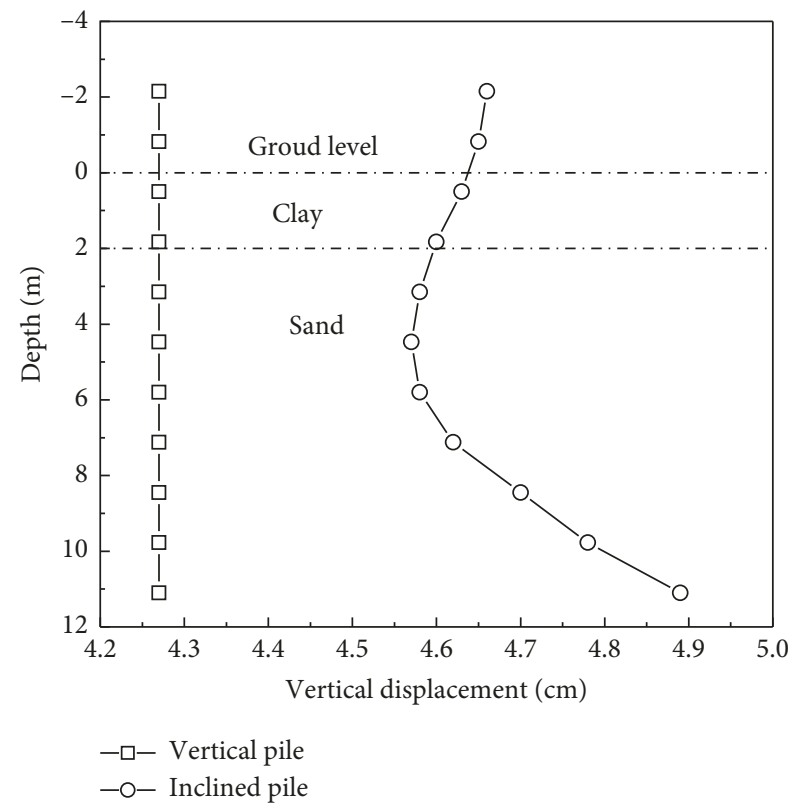

Figure 17: Vertical displacement of piles.

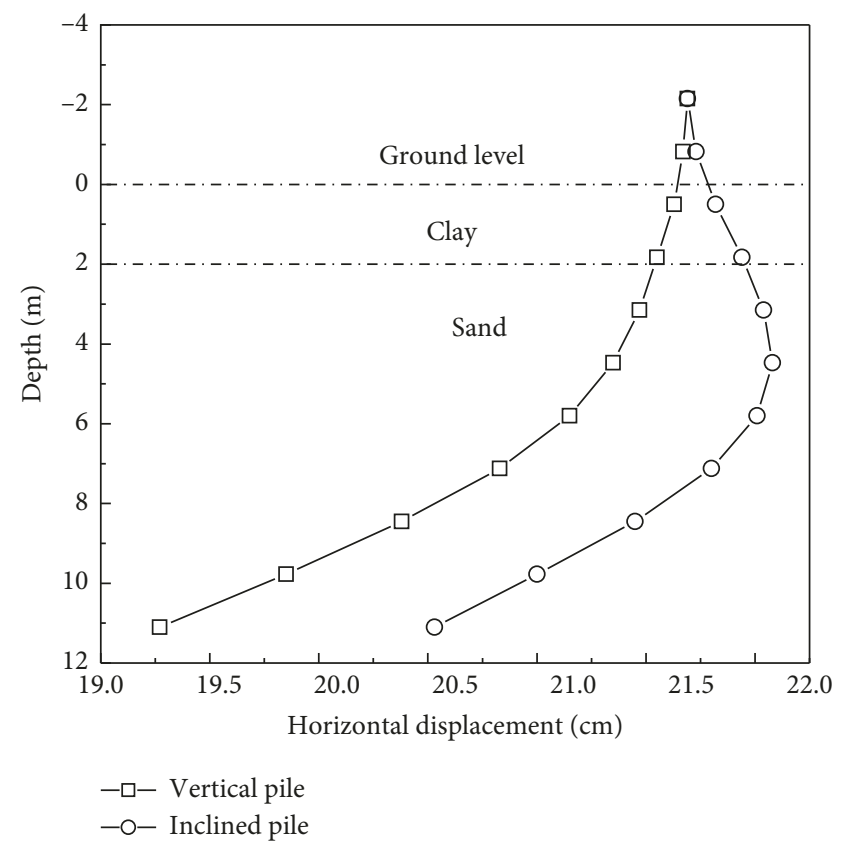

FIgURe 18: Horizontal displacement of piles.

displacement of vertical piles decreases gradually. While the maximum horizontal displacement of the inclined pile occurs in the middle of the pile foundation because of its bending.

\section{Comparative Analysis of Numerical Results for Different Types of Caps}

4.1. Comparative Analysis of Pile Bending Moment. For convenience, the model of oblique-straight alternating pile groups with low caps is referred to as model 1, and the model 


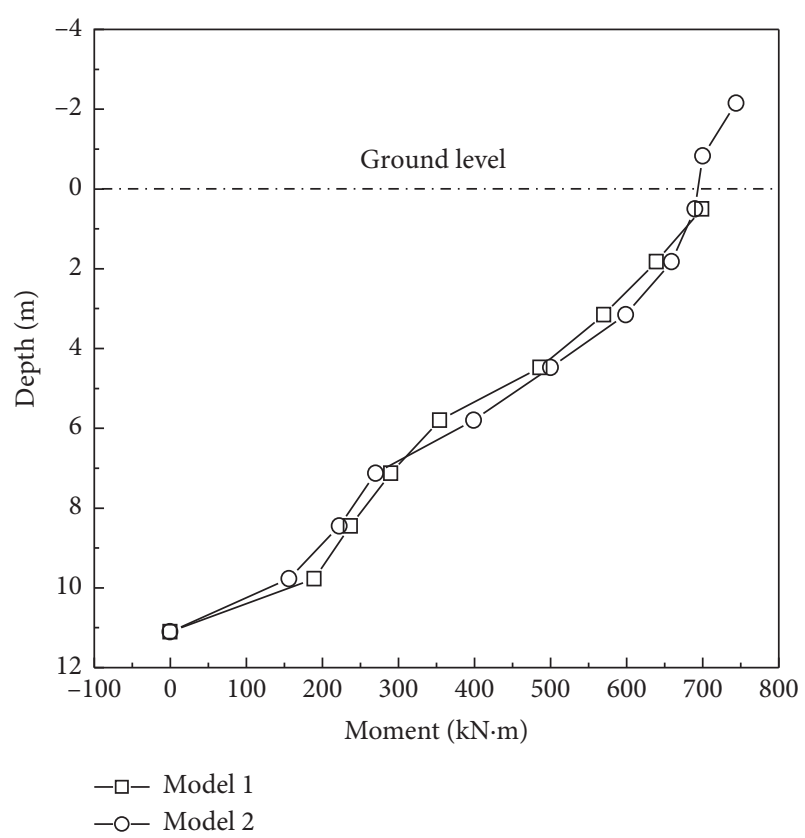

Figure 19: Contrastive analysis of bending moment of inclined piles.

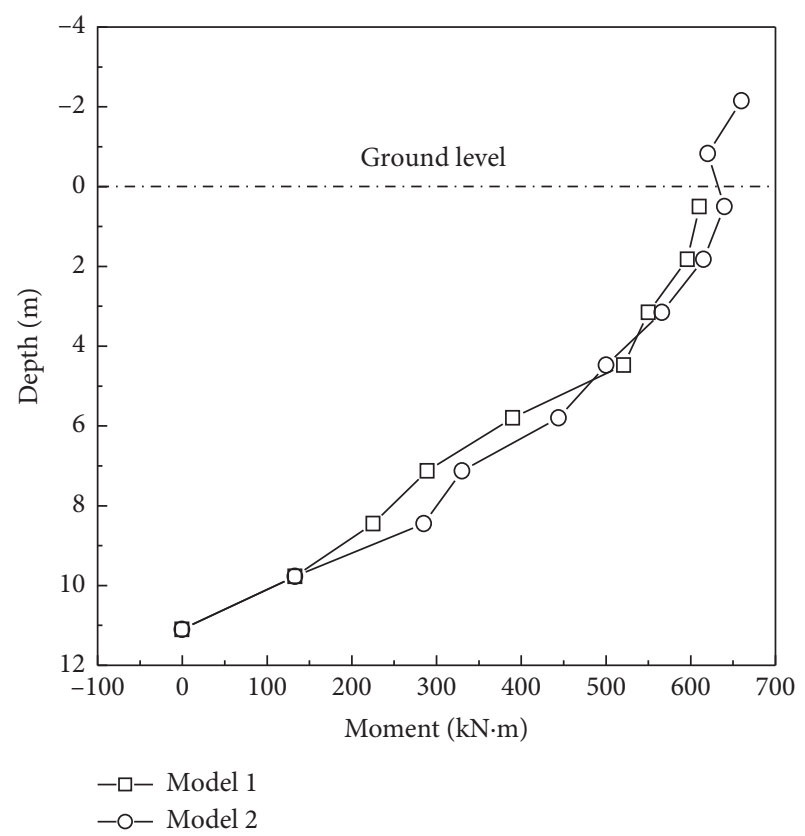

FIGURE 20: Contrastive analysis of bending moment of vertical piles.

of oblique-straight alternating pile groups with high caps is referred to as model 2 . The maximum bending moments of inclined piles at different burial depths in the dynamic calculation of the two models are taken. Figure 19 shows the relationship curve between the bending moments of inclined piles and buried depth. The minimum bending moment of inclined piles in both models is zero, and both of them appear at the end of pile foundation. The maximum bending moment of inclined piles in both models occurs at the

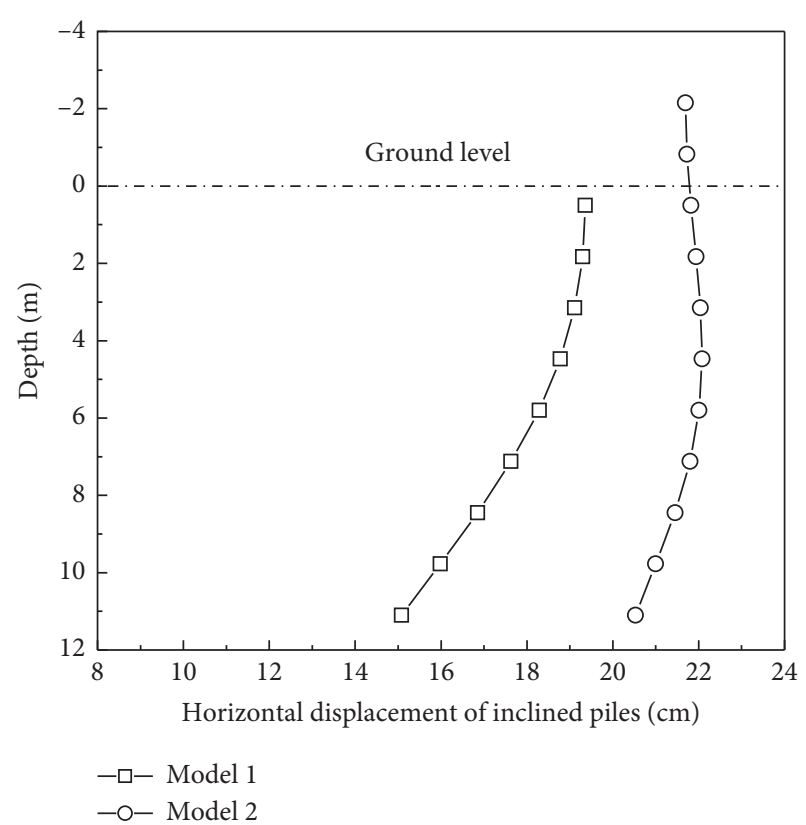

Figure 21: Contrastive analysis of horizontal displacement of inclined piles.

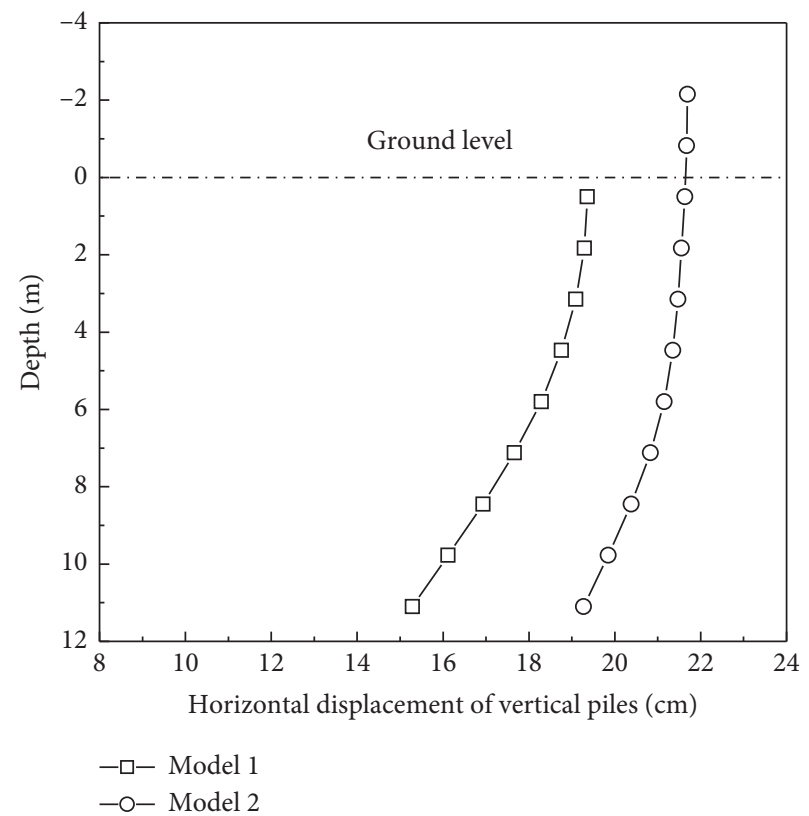

Figure 22: Contrastive analysis of horizontal displacement of vertical piles.

junction of piles and the cap. The maximum bending moment of the second model is larger than that of the first model, and the influence of the cap form on the bending moment of piles is small.

Through comparison in Figure 20, it is found that the difference between the two models is small; especially at the end of the pile foundation, the values of the two models are basically the same. The influence of the cap form on the bending moment of the straight pile is small. 


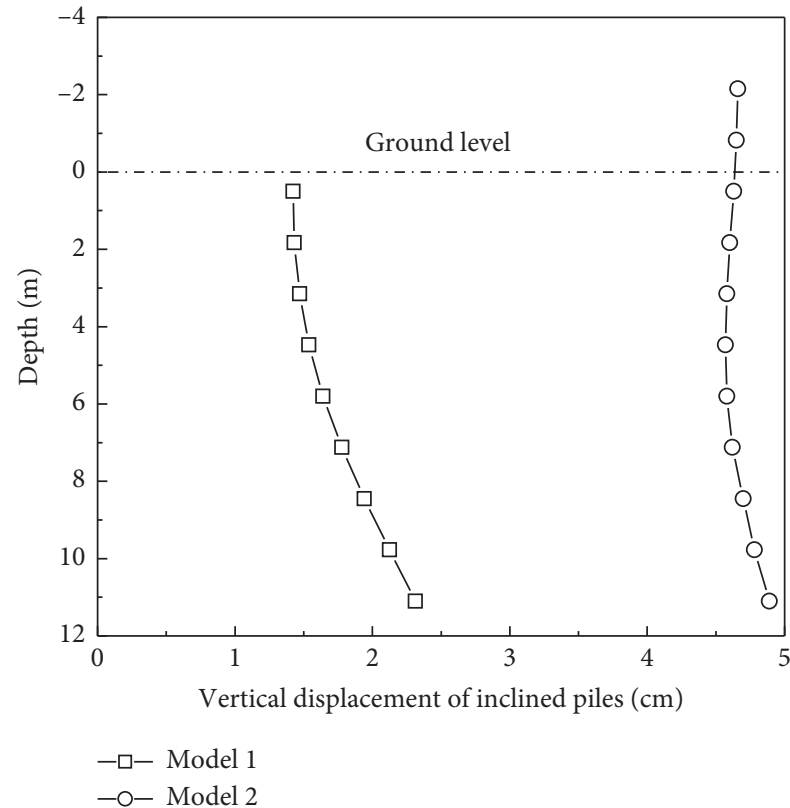

FIGURE 23: Contrastive analysis of vertical displacement of inclined piles.

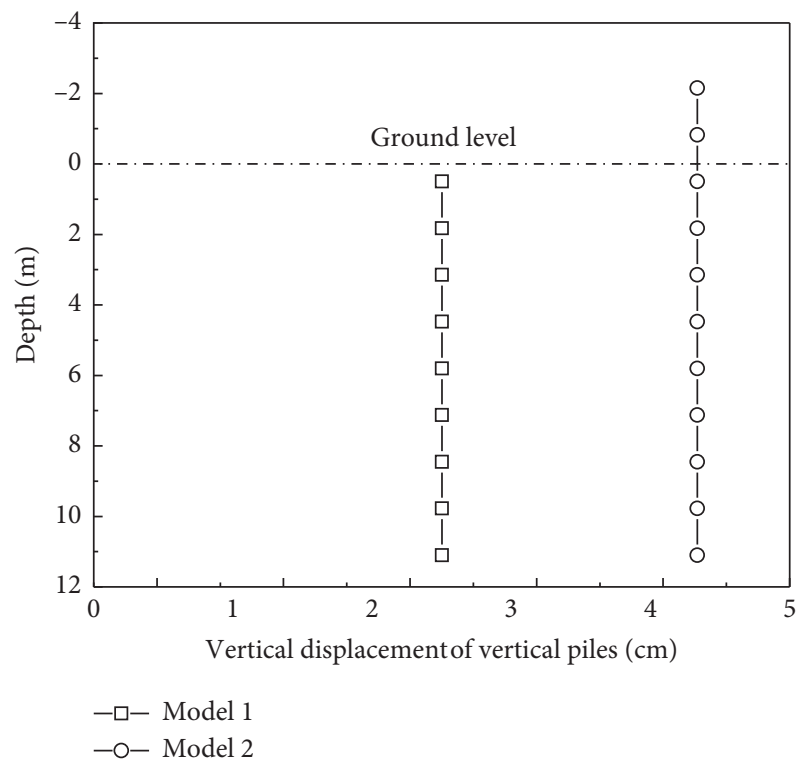

FIGURE 24: Contrastive analysis of vertical displacement of vertical piles.

4.2. Comparative Analysis of Pile Displacement. The relationship curves between the final horizontal displacement and the buried depth of the inclined pile and vertical pile are shown in Figures 21 and 22, respectively. The reason why the horizontal displacement of model 2 is larger than that of model 1 is due to the influence of the cap. Because model 1 is a low cap and the cap is in the clay layer, the side of the cap will be bound by the clay layer in the process of vibration. Model 2 belongs to the high cap model, and the lateral resistance of the structure is obviously smaller.

The relationship curves between the final vertical displacement and the depth of the inclined pile and the vertical

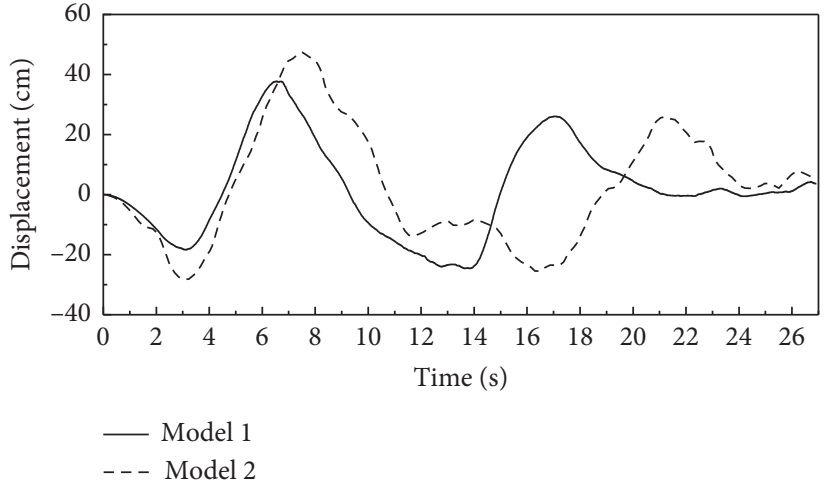

FIGURE 25: Contrastive analysis of horizontal displacement timehistory curve for the top of pier.

pile are shown in Figures 23 and 24, respectively. It can be seen that the vertical displacement of model 2, whether inclined or vertical, is significantly larger than that of model 1.

The reason is that the second model belongs to the high cap model, and all loads of the superstructure are assumed by the pile foundation, while the first model belongs to the low cap model. The so-called cap effect exists in the bearing force. The bottom part of the cap bears a part of the load, resulting in the reduction of the load on the pile body and the corresponding reduction of the vertical displacement of the pile foundation.

4.3. Contrastive Analysis of Horizontal Displacement of Pier Top. The horizontal displacement time-history curves of the top of the piers of the two models along the $x$-direction are shown in Figure 25. The horizontal displacement of the pier top of the two models is zero at the beginning, and the horizontal displacement begins to change with time. By the end of $27 \mathrm{~s}$, the horizontal displacement tends to zero. In the whole dynamic calculation stage, the maximum horizontal displacement of model 2 is obviously larger than that of model 1 . The time of the maximum horizontal displacement of model 1 is almost the same as that of model 2, and it occurs about 7 seconds after liquefaction.

The reason why the time-history curves of horizontal displacement of pier top are different between the two models is that model 2 belongs to the high cap model, the structure is longer above the ground level, and there is no embedded effect of soil on the cap. It is easy to form voids between the pile body and soil, so the maximum horizontal displacement of pier top is larger.

\section{Conclusions}

(1) The instantaneous negative value of pore pressure due to soil dilatation occurs when the peak vibration acceleration of the upper and lower regions of pile foundation in the sandy soil layer occurs. The liquefaction is easy to occur in the middle area of the pile, but the liquefaction of the sand layer is not obvious in the upper area of the pile because the 
groundwater penetrates the upper clay layer, and the liquefaction of the sand layer is not easy to occur in the bottom area of the pile because of the thicker overlying layer and the higher consolidation pressure.

(2) In the same model, the maximum bending moment of vertical piles is less than that of inclined piles. In different models, the maximum bending moment of inclined piles and the vertical piles occurs at the junction of the piles and the cap, and the bending moment of the piles with high cap is larger from the bottom of the cap to the ground level.

(3) In the model that piles with low cap, the horizontal displacement of the inclined piles and vertical piles is the same. The maximum horizontal displacement occurs at the top of the all piles. The vertical displacement of the vertical pile is a constant value, while the vertical displacement of the inclined pile varies along the buried depth. In the high cap model, the horizontal displacement of the inclined pile along the buried depth is no longer monotonous, and the maximum value appears in the sand layer. Compared with different models, the vertical and horizontal displacements of the piles with high cap are significantly larger than those piles with low cap at the same buried depth.

(4) The maximum horizontal displacement of the pier top with high cap is larger than that with low cap; the maximum horizontal displacement of the pier top of the two models occurs at the same time.

\section{Data Availability}

The data used to support the findings of this study are included within the article.

\section{Conflicts of Interest}

The authors declare that there are no conflicts of interest regarding the publication of this paper.

\section{Acknowledgments}

This work was supported by the Natural Science Foundation of China (41372288) and the Shandong Natural Science Foundation (ZR2019MEE027).

\section{References}

[1] R. J. Armstrong, R. W. Boulanger, and M. H. Beaty, "Equivalent static analysis of piled bridge abutments affected by earthquake-induced liquefaction," Journal of Geotechnical and Geoenvironmental Engineering, vol. 140, no. 8, Article ID 04014046, 2014.

[2] S. Escoffier, "Experimental study of the effect of inclined pile on the seismic behavior of pile group," Soil Dynamics and Earthquake Engineering, vol. 42, no. 4, pp. 275-291, 2012.

[3] W. Li, Z. Gang, and N. O. Ruo, "Finite element analysis of couple effect of soil displacement and axial load on single inclined pile," Journal of Central South University, vol. 21, no. 9, pp. 3656-3664, 2014.

[4] F. Zhang, K. Okawa, and M. Kimura, "Centrifuge model test on dynamic behavior of group-pile foundation with inclined piles and its numerical simulation," Frontiers of Architecture and Civil Engineering in China, vol. 2, no. 3, pp. 233-241, 2008.

[5] C. W. Lu, M. W. Gui, and S. C. Lai, "A numerical study on soil-group-pile-bridge-pier interaction under the effect of earthquake loading," Journal of Earthquake and Tsunami, vol. 08, no. 01, Article ID 1350037, 2014.

[6] D. S. Kong, M. X. Deng, and Z. M. Zhao, "Seismic interaction characteristics of an inclined straight alternating pile groupsoil in liquefied ground," Advances in Civil Engineering, vol. 2019, Article ID 3758286, 12 pages, 2019.

[7] D. S. Kong, M. X. Deng, Y. Liu et al., "study of the force and deformation characteristics of subsea mudmat-pile hybrid foundations," Polish Maritime Research, vol. 25, no. 3, pp. 43-53, 2018.

[8] D. S. Kong, M. X. Deng, and Y. Xu, "Study on calculation of pile sliding interval of large-diameter steel pile piles on offshore platforms," Mathematical Problems in Engineering, vol. 2019, Article ID 3549296, 8 pages, 2019.

[9] A. Rahmani and A. Pak, "Dynamic behavior of pile foundations under cyclic loading in liquefiable soils," Computers and Geotechnics, vol. 40, pp. 114-126, 2012.

[10] G. Ye, Y. Cai, and Z. Zhang, "Numerical study on load transfer effect of stiffened deep mixed column-supported embankment over soft soil," KSCE Journal of Civil Engineering, vol. 21, no. 3, pp. 703-714, 2016.

[11] B. Maheshwari and R. Sarkar, "Effects of soil nonlinearity and liquefaction on seismic response of pile groups," International Journal of Geotechnical Engineering, vol. 6, no. 4, pp. 497-506, 2012.

[12] X. Gao, X.-Z. Ling, L. Tang, and P.-J. Xu, "Soil-pile-bridge structure interaction in liquefying ground using shake table testing," Soil Dynamics and Earthquake Engineering, vol. 31, no. 7, pp. 1009-1017, 2011.

[13] Y. M. Chen and D. P. Xu, FLAC/FLAC3D Foundation and Engineering Practice, WaterPower Press, Beijing, China, 2009.

[14] M. R. Taha, J. M. Abbas, Q. S. Shafiqu, and Z. H. Chik, "The performance of laterally loaded single pile embedded in cohesionless soil with different water level elevation," Journal of Applied Sciences, vol. 9, no. 5, pp. 909-916, 2009. 


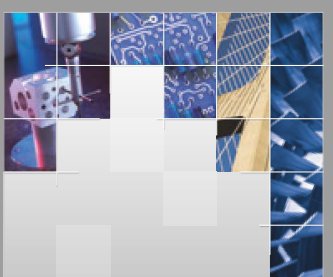

\section{Enfincering}
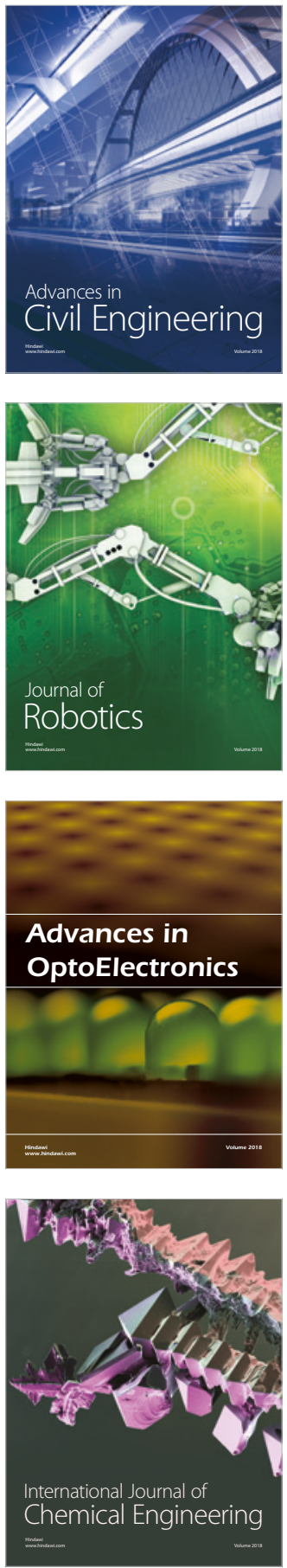

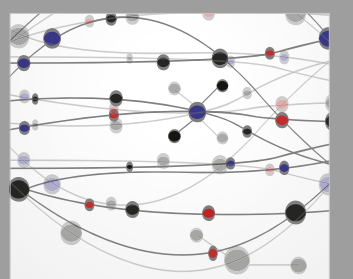

\section{Rotating \\ Machinery}

The Scientific World Journal

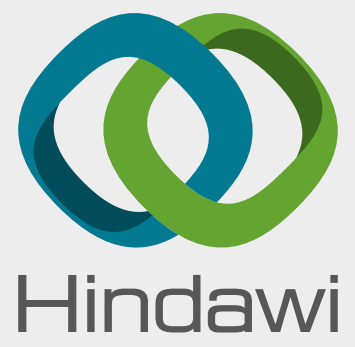

Submit your manuscripts at

www.hindawi.com
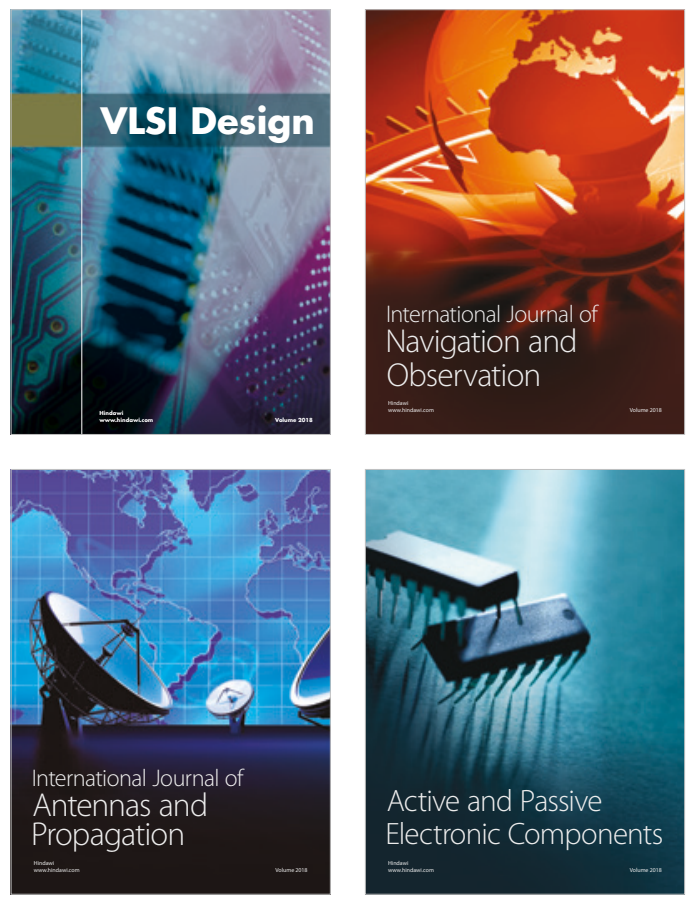
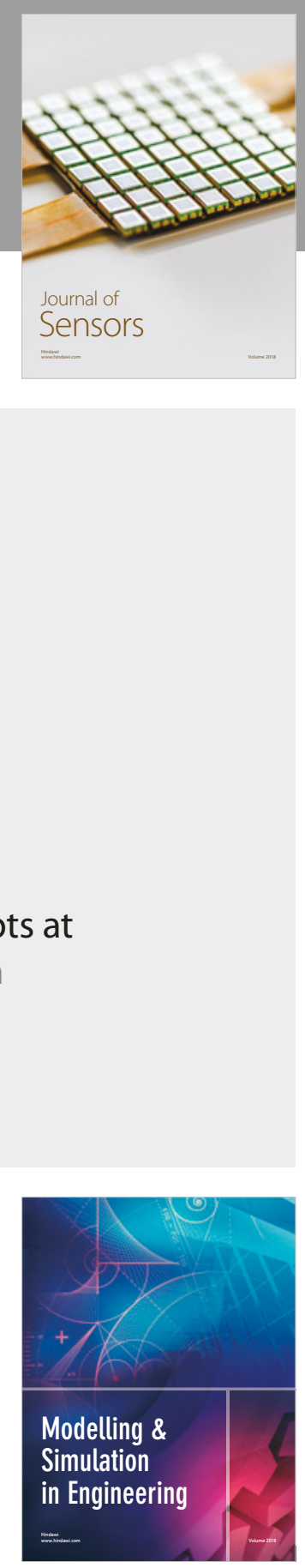

\section{Advances \\ Multimedia}
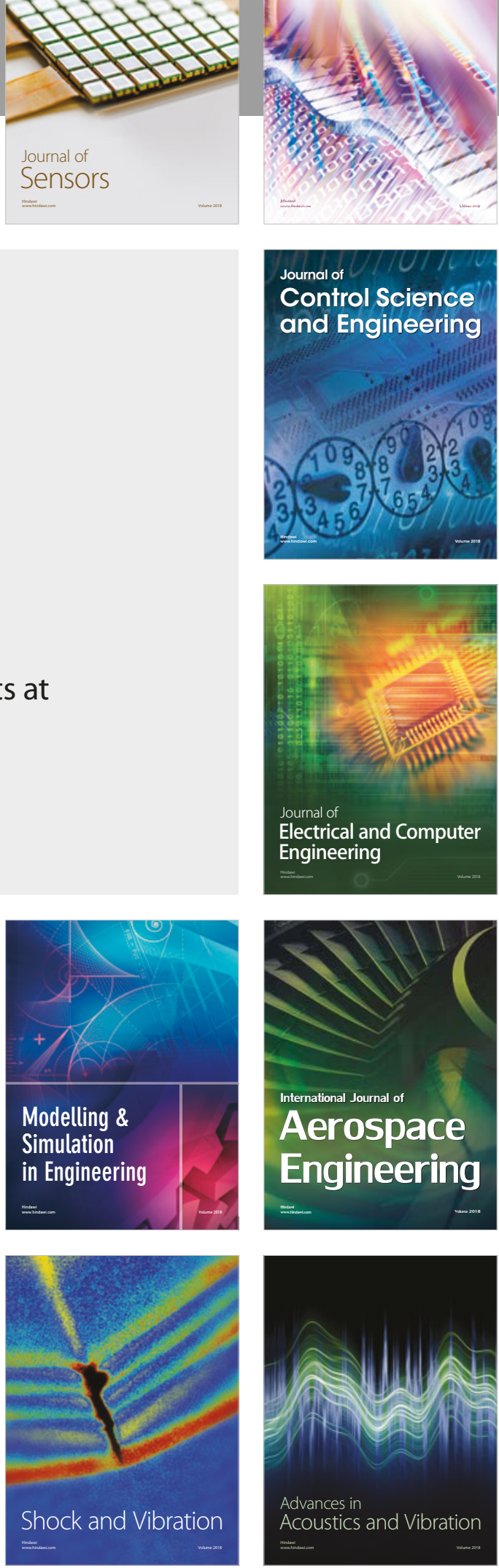